\title{
The Effect of Social Media Marketing on Brand Awareness through Facebook: An Individual-Based Perspective of Mobile Services Sector in Egypt
}

\author{
Hana Othman ElAydi \\ Arab Academy for Science, Technology \& Maritime Transport, Alexandria, Egypt \\ Email: hana.elaydi@gmail.com
}

How to cite this paper: ElAydi, H.O. (2018) The Effect of Social Media Marketing on Brand Awareness through Facebook: An Individual-Based Perspective of Mobile Services Sector in Egypt. Open Access Library Journal, 5: e4977.

https://doi.org/10.4236/oalib.1104977

Received: October 10, 2018

Accepted: October 26, 2018

Published: October 29, 2018

Copyright (๑) 2018 by author and Open Access Library Inc.

This work is licensed under the Creative Commons Attribution International License (CC BY 4.0).

http://creativecommons.org/licenses/by/4.0/ (c) (i) Open Access

\begin{abstract}
The growing usage of social media is changing the businesses' method responding to consumer's needs and wants and increasing the chances for firms to market their products and services in a customized and personal way. Nevertheless, there are still needed answers concerning to what extent social media platforms as marketing tools are being employed by companies and their effect on brand awareness in mobile service providing industry in Egypt. The purpose of this study is to investigate the impact of social media marketing activities on Facebook on brand awareness keeping into consideration the moderating effect of demographics, namely; age and gender. The research showed that social media marketing firms use mainly about six dimensions as an instrument for their marketing activities: Online Communities, Interaction, Sharing of Content, Accessibility, and credibility. Also, this research is testing the demographics moderation role in the relationship between social media marketing activities on Facebook and consumer based brand awareness. Moreover, practical importance of this research is described in the fact that managers may use the results to improve their marketing activities related to social networks specially their Facebook fan pages to have better brand awareness of their brands. Besides, firms may start to integrate social media marketing into their marketing strategies, improving communication and interaction with their customers and increase their brand awareness circle. A sample of the study totaled 402 customers; the researcher tested the hypothesis using the correlation analysis, regression analysis using SPSS and structure equation model using AMOS. This research provides an evidence of the relationship between social media marketing activities on Facebook and brand awareness of mobile service providers in Egypt.
\end{abstract}




\section{Subject Areas}

Business Research Methods, Consumer Behavior, Marketing

\section{Keywords}

Social Media Marketing, Brand Awareness, Online Communities, Facebook

\section{Introduction}

Nowadays, marketing is changing faster than ever. Everyday new communication means appear. Recently, media have been categorized into traditional and non-traditional approaches. TV and newspapers are examples of such traditional media. Customers are now increasingly using social media to connect, look for, and exchange information, thoughts, and experiences of brands and companies. Facebook, MySpace, YouTube, and Twitter are used to share experiences whether good or negative [1].

Product and company profile and information on social media networks are assumed to be reliable and credible sources, more dependable and proper than the traditional marketing [2]. According to researchers in traditional marketing, consumers will tell seven to ten individuals about the product, but now social media permits consumers to share experiences with other customers in no time [3]. From a marketing standpoint, social media network is now a vital part of an organization's media mixes that revolutionize the way consumers and marketers connect. It also offers new opportunities to spread to potential consumers. Social media in marketing has generated two important opportunities for all types of businesses. First, companies now have contact to a massive collection of social media tools that can be employed for various marketing purposes, such as marketing communication, market research, customer service, product management, and word-of-mouth (WOM) marketing [4]. Secondly, marketers use social media as a crucial role of their marketing strategies. It has the power to attain great results on productivities, competitive position and customer value for least budget and time.

Social media was found that it plays a vital role in building a brand as well. Consumer-based brand equity is the intangible evaluation of the brand and subjective for consumers, as a result it's objectively perceived value. Four main dimensions of brand equity are customer brand awareness and associations, customer brand loyalty and perceived brand quality [5]. At a global level, social media and its platforms (like Facebook, Twitter, MySpace, and LinkedIn), are projecting online activity in terms of average consumed time or index and number of engagement and active users. It was assumed that time spent on social media sites is rising at more than three times the rate of total Internet progression. The Internet users visiting social networking sites at least once a month is predicted to grow from $41 \%$ in 2008 to above $65 \%$ in 2014 [6]. 
Egypt has a massive increase in the number users of Internet and social media in 2017. Accordingly, the number of Internet user in Egypt has reached 49.2 million $49.5 \%$ penetration [7]. Furthermore, mobile subscribers have reached 110.06 million in September 2017 [8]. Besides the recent statistics estimated that 26.3 million Egyptians use smartphones. In Egypt, individuals go online to search for information (78\%) or to communicate with others (77\%). More than 22 million Egyptians logon Facebook every month. Facebook contains around 59\% of individuals that are daily users [9]. Social media penetration statistics are remarkable. It is more essential to look at the implications. Some researchers support businesses to improve their social media strategies and connect their brands online. Additionally, some companies performed proactively at the early stage of its adoption. Yet, there are still a large number of firms left behind. On the other hand, other researchers believe that social media networks are for communication (connecting people). Many firms underestimate its potential and think it is only another marketing channel to promote brands. Furthermore, some companies are commonly concerned about the real benefits of using social media in marketing.

There are many social media marketing activities on Facebook, which may be used in studies related to mobile service providers. In this research, activities (online communities, interaction, sharing of content, accessibility, and credibility) are considered [5] [10] [11]. The top Social Networking platforms provide extraordinary numbers-hundreds of millions of active users, hundreds of millions of discussions going on at these sites on every topic, seventy-two hours of video being uploaded every minute, a million blog posts every day, millions of daily Tweets, so the opportunities are limitless [5].

\section{Theoretical Framework}

\subsection{Social Media Marketing in Egypt}

Numerous statistics indicate the increasing use of social media in Egypt [12]. Studies indicate that social media has a crucial role in daily life of Egyptian Internet users. Egypt is ranked the seventeenth worldwide in terms of audience size and the first among Arab region countries [8]. The usage of YouTube is also high in Egypt, 44\% of Egypt's Internet users [13]. While social media penetration statistics are extraordinary, it is more important to look at the implications. Some investigators support firms to develop their social media strategies and connect their brands online. Moreover, some businesses predicted the social media marketing importance, taking steps at the early stage of its implementation. As an integrated marketing medium, social media marketing activities effectively enhance equity through introducing new values to their customers rather than the traditional marketing media. Therefore, it was concluded that brand's social media platforms offer variety of methods to the individuals who use it to interact and communicate with other users and brands [10]. As shown in the following Table 1 demonstrates the research variables definitions. 
Table 1. Research variables definition.

\begin{tabular}{ccl}
$\begin{array}{c}\text { Research Variable } \\
\text { Name }\end{array}$ & $\begin{array}{c}\text { Research } \\
\text { Variable Type }\end{array}$ & \multicolumn{1}{c}{ Definition } \\
$\begin{array}{c}\text { Online } \\
\text { Communities }\end{array}$ & $\begin{array}{c}\text { Independent } \\
\text { Variable }\end{array}$ & $\begin{array}{l}\text { A company or business is able to exploit the social media to } \\
\text { form a community related to its products/business [5] [14]. }\end{array}$ \\
Interaction & $\begin{array}{c}\text { Independent } \\
\text { Variable }\end{array}$ & $\begin{array}{l}\text { A Facebook page or Twitter account can notify all its } \\
\text { followers of specific subject quickly and simultaneously [5] [10]. }\end{array}$ \\
Sharing of & $\begin{array}{c}\text { Independent } \\
\text { Variable }\end{array}$ & $\begin{array}{l}\text { This factor is about the level that an individual interchange, } \\
\text { spreads and accepts content in a social media setting [5] [10]. }\end{array}$ \\
Accessibility & $\begin{array}{c}\text { Independent } \\
\text { Variable }\end{array}$ & $\begin{array}{l}\text { The social media is easily reachable and takes minimum or no } \\
\text { costs for usage [5]. }\end{array}$ \\
& Independent \\
Variable & $\begin{array}{l}\text { It is entirely about delivering message in clear way to the } \\
\text { individuals, founding credibility for what you say or do, linking } \\
\text { emotionally with your target audience, create motive to the } \\
\text { bredibility }\end{array}$ & $\begin{array}{l}\text { buyer and generating loyal customers [5] [14]. } \\
\text { The strength of the trace of a brand in consumer memory, as } \\
\text { reflected by the consumers' ability to identify the brand under } \\
\text { different conditions [15]. }\end{array}$ \\
& Dependent \\
Variable
\end{tabular}

\subsection{Brand Awareness}

Brand awareness was defined by as the "strength of a brands presence in the consumers mind". That means, brand awareness is a customer's ability to identify or remember a brand in its product group [16]. Brand associations can be assumed as "whatever customer connects to brand. It can involve customer image-making, outline of the product, consumer's conditions, company awareness, product/ service characteristics, signs and symbols" [17]. Nevertheless, practical indication shows that brand awareness and brand associations could be combined into an exact dimension named brand awareness and associations.

Brand awareness connected with strong associations generates a specific brand image. Brand associations involve numerous episodes, ideas, facts, and instances that include a network of brand knowledge. These associations are vital to marketers and directors in brand positioning and differentiation practices, as well as generating positive attitudes toward brands. Additionally, brand associations are more effective when they are built on many experiences or exposures to communications [16].

\section{Literature Review}

\subsection{Social Media Perception}

Nowadays, social media is an extensively used tool, not only to participate with each other but also to reach a specific person or group. There has been a shift in power to consumers, as they change from inactive receivers of marketing content to active participants in the brand message. Interactive experiences was suggested that social media stimulates many customer behavior features, in- 
volving purchase behavior, information achievement and post-purchase communication. Also, Social media enables interaction as it allows one person to communicate easily with hundreds or thousands of other users in a rapid way [3]. Social media can be defined as applications that permit customers to communicate by generating personal information profiles, inviting whoever they want, to be friends with others, colleagues or strangers to be able to access these profiles, and direct messages to be sent among each other. Profiles include videos, photos and blogs [18].

Social media is suggested to have a numerous of forms and work on various platforms, including weblogs, social blogs and networks, microblogs, wikis, podcasts, photo and video sharing, online rating and social bookmarking [19]. Also, it provides a virtual area for individuals to keep in touch. Hence, Social media networks gives individuals new techniques to increase their social networks, through creating and maintaining social communication, creating interaction, sharing information, writing content, and participating in social movements through the Internet [3]. In addition, Social media gives businesses the chance to share and swap information with their users. Regarding to the study conducted by DiMauro and Bulmer [20], 71\% of the customers habitually read social media platforms as a daily routine. Nearly, $90 \%$ of usage on social media was related to brands.

\subsection{Theoretical Framework}

\subsubsection{Social Media Marketing}

Social media marketing is marketing strategies that successful businesses are using in order to be a part of a network of consumers online. Also, it could be defined as employing the Social Media as instruments of communication, direct sales, customer gain, and customer retaining [21]. In 2008 D.E.I. made a study that delivers some important statistics: social media users have visited social media platforms to obtain information are $70 \%$; also $49 \%$ of these customers have taken a decision of purchase established on the information they found through the social media sites; likewise, $60 \%$ described using social media platforms to exchange information with others online; and finally, $45 \%$ of users who searched for information over social media sites interacted with word-of-mouth. The report concludes that businesses not using social media as part of their online marketing strategy are losing an opportunity to influence and reach customers. Following Figure 1 demonstrates the study model.

\subsubsection{Hypothesis}

H1: There is a significant impact of Social media marketing activities in Facebook on Brand awareness of the mobile service providers consumers.

H2: Age and Gender moderate the relationship between Social media marketing activities on Facebook and Brand Awareness in the mobile service providers' consumers. 


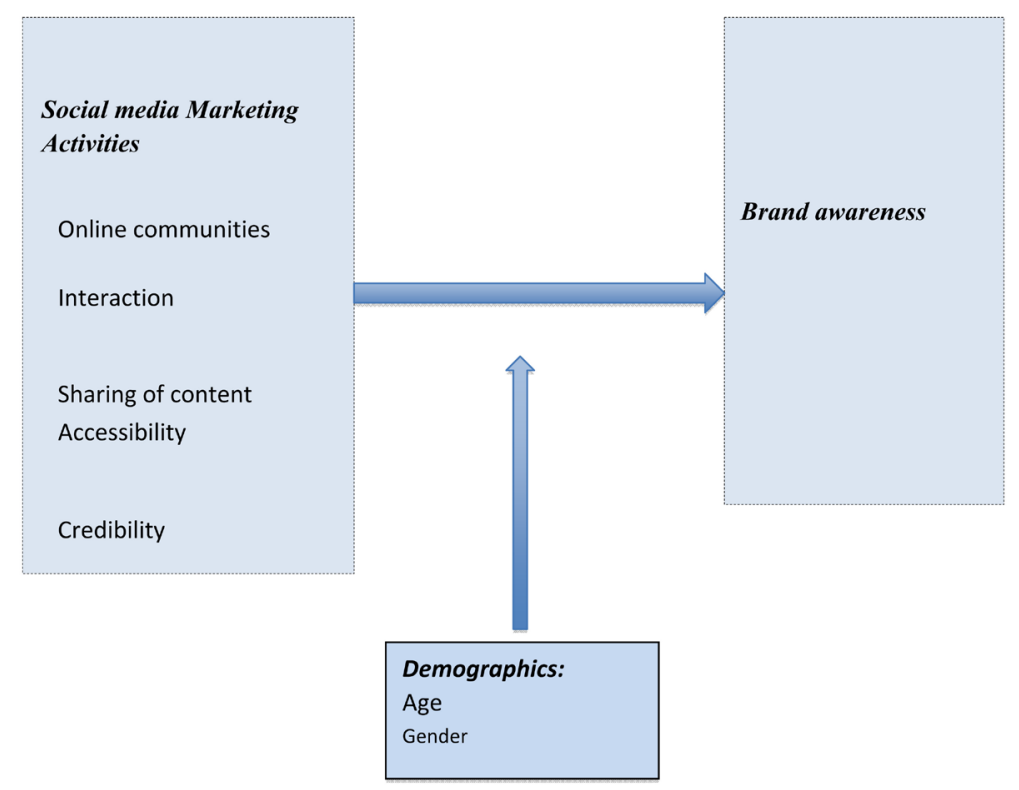

Figure 1. Research model. Source: [5] [10] [15].

\section{Methodology}

The following Table 2 includes the research methodology with definitions.

\subsection{Measurements Tools}

Likert five scales was applied in asking the questionnaire questions and measuring the study variables which is organized as strongly disagree to strongly agree and which takes the weight of ( 1 - 5), the measurement approach is matches with the study population and is tested in precedent studies.

\subsection{Statistical Analysis}

For the purpose of the study descriptive statistics were computed using SPSS software statistical package in analyzing the data obtained from the sample.

\subsection{Study Instruments}

The electronic questionnaire was developed to collect data from the sample of the study after assessing some of the previous literature addressing each of the variables examined in the study, it contains three categories of questions, the first group is about demographic questions (marital status, gender, age, and education) about the study population, the second is about social media applications as a tool of marketing was covered by (36) questions: online communities (7) questions, sharing of content (6) questions, interaction (7) questions, accessibility (7) questions, credibility (6) questions, [10] [11] [22] [23] [24]. The third category is about brand awareness which was covered by 10 questions [22].

\subsection{Study Validity}

Validity for the questionnaire was obtained from the researcher conducted 
Table 2. Research methodology summary.

\begin{tabular}{|c|c|}
\hline Item & Description \\
\hline Approach & The current research is a descriptive research. \\
\hline Population & Users of mobile network service providers through Social Media in Egypt. \\
\hline $\begin{array}{l}\text { Sampling } \\
\text { Techniques }\end{array}$ & $\begin{array}{l}\text { The sampling technique used for questionnaire is clustered random } \\
\text { sampling, which depends on selecting a random sample from users of mobile } \\
\text { network service providers through Social Media. }\end{array}$ \\
\hline Sample Size & 402 users of mobile network service providers through Social Media. \\
\hline Data collection & $\begin{array}{l}\text { Interviews directed to frequent users of Social Media } \\
\text { Questionnaires directed for users of mobile network service providers } \\
\text { through Social Media. }\end{array}$ \\
\hline Statistical Packages & $\begin{array}{l}\text { SPSS } \\
\text { AMOS }\end{array}$ \\
\hline Unit of Analysis & $\begin{array}{l}\text { The sample consisted of all the customer of the Egypt mobile service } \\
\text { providers who has activities in these companies' Facebook page. This sample } \\
\text { is distributed on the three companies (Vodafone, Etisalat, We, and Orange). }\end{array}$ \\
\hline Sampling Design & Probability Sampling \\
\hline Time Horizon & Cross sectional \\
\hline
\end{tabular}

another pilot study to check the convergent validity. The following section displays the results from the pilot study of 30 respondents.

\subsection{Study Reliability}

Reliability refers to the internal consistency between statements of one factor. It is tested using Cronbach's Alpha, which is the most commonly used test of reliability. Alpha coefficient ranges in from 0 to 1 , where the higher the score, the more reliable the generated scale is. Alpha coefficients are claimed to exceed 0.7 to refer to an adequate reliability. The Cronbach alpha was as follows for each variables of the study: online communities, 0.832 , interaction, 0.753 , content sharing, 0.866 , accessibility, 0.765 , credibility, 0.799 , brand awareness, 0.856

\section{Study Results}

Demographic \& Study sample Characteristics:

The results are shown in Table 3 the descriptive variables for the 402 sample.

\section{Characteristics for the Study Sample}

Table 4 shows the correlation matrix between Social Media Marketing; Online Communities, Interaction, Sharing of Content, Accessibility, and Credibility and one of the dependent variables of Brand equity; Brand Awareness. It was observed that the value of Pearson's correlation for the research variables; Social Media Marketing; Online Communities, Interaction, Sharing of Content, Accessibility, and Credibility, are $0.398,0.307,0.480,0.580,0.606$ respectively, with $\mathrm{P}$-values of 0.000 ( $\mathrm{P}$-value $<0.05$ ). Thus, there is a significant positive moderate correlation between the research variables; Online Communities, Interaction, 
Table 3. Descriptive analysis for the research variables.

\begin{tabular}{|c|c|c|c|c|c|c|c|c|}
\hline \multicolumn{9}{|c|}{ Descriptive Statistics } \\
\hline & \multirow{2}{*}{$\mathbf{N}$} & \multirow{2}{*}{ Mean } & \multirow{2}{*}{ Std. Deviation } & \multicolumn{5}{|c|}{ Frequency-Percentage } \\
\hline & & & & 1 & 2 & 3 & 4 & 5 \\
\hline Online Communities & 402 & 2.8433 & 0.62197 & 0.7 & 25.4 & 63.4 & 9.7 & 0.7 \\
\hline Interaction & 402 & 2.6468 & 0.85310 & 1 & 56.7 & 19.4 & 22.4 & 0.5 \\
\hline Share of Content & 402 & 2.7935 & 0.57777 & 0.7 & 26.4 & 66.2 & 6.2 & 0.5 \\
\hline Accessibility & 402 & 2.6891 & 0.81466 & 0.5 & 51.2 & 27.9 & 19.7 & 0.7 \\
\hline Credibility & 402 & 2.6866 & 0.73479 & 0.7 & 45.3 & 38.6 & 15.4 & 0 \\
\hline Brand Awareness & 402 & 3.0323 & 0.64452 & 0 & 19.2 & 58.5 & 22.4 & 0 \\
\hline
\end{tabular}

Table 4. Correlation matrix between social media marketing and brand awareness.

\begin{tabular}{|c|c|c|c|c|c|c|c|}
\hline & & 1 & 2 & 3 & 4 & 5 & 6 \\
\hline \multirow{4}{*}{$\begin{array}{c}\text { Online } \\
\text { Communities }\end{array}$} & Pearson Correlation & 1 & & & & & \\
\hline & & & & & & & \\
\hline & Sig. (2-tailed) & & & & & & \\
\hline & $\mathrm{N}$ & 402 & & & & & \\
\hline \multirow{3}{*}{ Interaction } & Pearson Correlation & $0.201^{\star *}$ & 1 & & & & \\
\hline & Sig. (2-tailed) & 0.000 & & & & & \\
\hline & $\mathrm{N}$ & 402 & 402 & & & & \\
\hline \multirow{3}{*}{ Share of Content } & Pearson Correlation & $0.389^{\star *}$ & 0.095 & 1 & & & \\
\hline & Sig. (2-tailed) & 0.000 & 0.058 & & & & \\
\hline & $\mathrm{N}$ & 402 & 402 & 402 & & & \\
\hline \multirow{3}{*}{ Accessibility } & Pearson Correlation & $0.317^{\star *}$ & $0.114^{\star}$ & $0.229^{* *}$ & 1 & & \\
\hline & Sig. (2-tailed) & 0.000 & 0.022 & 0.000 & & & \\
\hline & $\mathrm{N}$ & 402 & 402 & 402 & 402 & & \\
\hline \multirow{3}{*}{ Credibility } & Pearson Correlation & $0.443^{\star \star}$ & $0.205^{\star *}$ & $0.393^{\star *}$ & $0.657^{\star *}$ & 1 & \\
\hline & Sig. (2-tailed) & 0.000 & 0.000 & 0.000 & 0.000 & & \\
\hline & $\mathrm{N}$ & 402 & 402 & 402 & 402 & 402 & \\
\hline \multirow{3}{*}{ Brand awareness } & Pearson Correlation & $0.398^{\star *}$ & $0.307^{\star *}$ & $0.480^{\star *}$ & $0.580^{\star *}$ & $0.606^{* *}$ & 1 \\
\hline & Sig. (2-tailed) & 0.000 & 0.000 & 0.000 & 0.000 & 0.000 & \\
\hline & $\mathrm{N}$ & 402 & 402 & 402 & 402 & 402 & 402 \\
\hline
\end{tabular}

Sharing of Content, and Accessibility, and Brand Awareness as corresponding $\mathrm{P}$-values are less than 0.05 and $\mathrm{r}>0$.

Table 5 shows the multiple regression analysis of Social Media Marketing; Online Communities, Interaction, Sharing of Content, Accessibility, and Credibility 
Table 5. Regression analysis of social media marketing effect on brand awareness.

\begin{tabular}{cccccccc}
\hline \multirow{2}{*}{ Model } & \multicolumn{2}{c}{$\begin{array}{c}\text { Unstandardized } \\
\text { Coefficients }\end{array}$} & $\begin{array}{c}\text { Standardized } \\
\text { Coefficients }\end{array}$ & T & P-Value & R Square \\
\cline { 2 - 4 } & B & Std. Error & Beta & & & \\
\hline (Constant) & 0.411 & 0.139 & & 2.962 & 0.003 & \\
Online Communities & 0.052 & 0.041 & 0.050 & 1.249 & 0.213 & \\
Interaction & 0.142 & 0.027 & 0.188 & 5.332 & 0.000 & \multirow{2}{*}{$\begin{array}{c}\text { B } \\
\text { Share of Content }\end{array}$} \\
Accessibility & 0.315 & 0.043 & 0.282 & 7.316 & 0.000 & \\
Credibility & 0.268 & 0.036 & 0.339 & 7.444 & 0.000 & \\
\hline
\end{tabular}

influence on Brand Awareness. It could be observed that there is a positive significant effect of SMM; Interaction, Sharing of Content, Accessibility, and Credibility on Brand Awareness, as the corresponding coefficients are 0.142, 0.315, 0.268 , and 0.186 respectively and the corresponding $\mathrm{P}$-values are 0.000 ( $\mathrm{P}$-value $<0.05)$. On the other hand, Online Communities is shown to have an insignificant influence on Brand Awareness in the presence of other Social media marketing activities on Facebook, as the corresponding p-value is 0.213 ( $\mathrm{P}$-value $>$ 0.05). Also, it was found that R square is 0.537 , which means that SMM Activities explain $53.7 \%$ of the variation in Brand Awareness.

Regarding the moderation role of gender and age between Social media marketing activities on Facebook and brand awareness, Table 6 shows the SEM analysis of the influence of Social Media Marketing; Online Communities, Interaction, Sharing of Content, Accessibility, and Credibility, and Interactions on Brand awareness. It could be observed that there is a significant moderation role of Age between Online Communities and Brand awareness, as the estimates are 0.559 , and 0.109 respectively as well as $\mathrm{P}$-values 0.23 , and 0.016 respectively. Also, the $\mathrm{R}$ square is 0.511 which means that the model explains $51.1 \%$ of the variation in awareness.

\section{Results Discussion}

\section{H1: There is a significant impact of Social Media Marketing Activities in} Facebook on brand awareness of the mobile service providers' consumers.

In this study, it could be claimed that there is a significant positive effect of Interaction, Sharing of Contents, Accessibility and Credibility on Brand Awareness, however there is an insignificant effect of online communities on Brand Awareness. Also, it was found that $\mathrm{R}$ square is 0.537 , which means that Social media marketing activities on Facebook; Online Communities, Sharing Contents, Interaction, Accessibility and Credibility explain $53.7 \%$ of the variation in Brand Awareness. This means that the first hypothesis is partially supported.

The mentioned results agreed with the study of Marzouk [12], who provided an evidence of the overall impact of Social Media Marketing Activities in Facebook on Brand Awareness. Most of respondents realized the importance of social 
Table 6. SEM Analysis of social media marketing and interactions on brand awareness.

\begin{tabular}{lccccc}
\hline & & & Estimate & P-Value & R Square \\
\hline Brand Awareness & $<---$ & Online Communities ${ }^{\star}$ Gender & -0.099 & 0.133 & \\
Brand Awareness & $<---$ & Interaction ${ }^{*}$ Gender & -0.092 & 0.241 & \\
Brand Awareness & $<---$ & Sharing of Content ${ }^{\star}$ Gender & 0.073 & 0.370 & \\
Brand Awareness & $<---$ & Accessibility ${ }^{\star}$ Gender & -0.008 & 0.901 & \\
Brand Awareness & $<---$ & Credibility ${ }^{\star}$ Gender & 0.142 & 0.171 & \multirow{2}{*}{0.511} \\
Brand Awareness & $<---$ & Online Communities ${ }^{\star}$ Age & 0.109 & 0.016 & \\
Brand Awareness & $<---$ & Interaction ${ }^{\star}$ Age & -0.100 & 0.063 & \\
Brand Awareness & $<---$ & Sharing of Content ${ }^{\star}$ Age & -0.007 & 0.909 & \\
Brand Awareness & $<---$ & Accessibility ${ }^{*}$ Age & -0.005 & 0.937 & \\
Brand Awareness & $<---$ & Credibility $^{*}$ Age & -0.003 & 0.976 & \\
\hline
\end{tabular}

media in the marketing efforts companies do and how it is employed in their activities. The results also agreed with Kim and Ko [10] who proved the significant relationship between Social media marketing activities on Facebook and Brand Equity. In addition, Karamian [15], proved the significant positive relationship between Social media marketing activities on Facebook and Brand Awareness. The same results were initiated by As' ad and Alhadid [5] who proved the significant effect of Social media marketing activities on Facebook except for Online Communities on Brand Equity.

H2: Age and Gender moderate the relationship between Social media marketing activities on Facebook and brand awareness in the mobile service providers' consumers.

The moderation role of Age and Gender on the relationship between Social media marketing activities on Facebook and brand awareness. It was computed and analyzed to check the effect of them on brand awareness. It was found that there is a significant moderation role of age in the relationship between online communities and brand awareness, with coefficient of 0.190 and P-value of 0.016 (P-value $<0.05)$.

The results of this hypothesis testing mean that age could enhance the relationship between online communities and brand awareness. It could be noticed that despite the fact that Online Communities was showing an insignificant effect on Brand Awareness, but the presence of different Age groups is able to turn this effect to a significant one. This indicates that younger age groups are able to trust each other and their reviews more than the older age groups. This result was clear from the responses found in the interviews during the qualitative study.

On the other hand, other moderation roles between Content Sharing, Accessibility and Credibility on one side and Brand Awareness on the other side are shown to be insignificant, as the corresponding P-values are greater than 0.05 . Furthermore, age as moderator for the relationship between Social media mar- 
keting activities on Facebook and brand loyalty showed insignificant moderation role. According to these outcomes, females are slightly getting attached to specific brand, become loyal to the brand create their own online community, and exchange news related to the brand and its offerings.

\subsection{Research Conclusion}

This research provides evidence of the relationship between Social media marketing activities on Facebook and brand awareness of mobile network services in Egypt. It also proved the moderation role of both; age and gender as the personal profiles of customers in the relationship between Social media marketing activities on Facebook and brand awareness of mobile network services in Egypt. The significance of hypotheses emphasizes the application of social media marketing activities in Facebook to strengthen their brand awareness, which is critical for most firms. The majority of firms in the industry were subject to this study. Results showed that social media is used for building or enhancing brand awareness that in turn may lead to increasing sales revenue in the future.

Companies should benefit from such exposure through the increase of brand Facebook page likes, which builds an online presence and adds to their circle of influence. Besides, impact of social media marketing on brand awareness includes obtaining high brand reach, enabling individuals to join in brand discussions and increases traffic or number of followers and the feedback that they deliver. The results also demonstrated that companies should engage with customers by increasing individuals to like brand posts, which drive content sharing and interaction. This will lead to an increase in the number of users added to a company circle of influence. Interaction, content sharing, and credibility are the highest of Social media marketing activities on Facebook of impact on brand awareness. Moreover, the age moderates only brand awareness and online communities; which could be utilized in perfect way through Facebook profiles that are following specific brands, to make specific channels for the younger age groups.

\subsection{Research Practical Recommendations}

The study findings have recommendations for marketers and managers to deploy efficiently Social media marketing activities on Facebook, and for understanding the role of social media marketing in developing strong brand awareness for companies.

First, the results of this study suggest that Social media marketing activities on Facebook are strongly related to brand awareness. Businesses can exploit the benefit of the daily and direct communication proposed by social media by maintaining brand relationship with current and possible customers. Using social media to spread brand name provides greater opportunity to increase brand awareness, keeping into consideration that females are influenced more with firms'online communities. 


\subsection{Research Limitations}

Like all research, this research has several limitations on how the study was handled. The limitation for this research faced time limitation to finish the research, which was a constraint for collecting larger sample size to represent the data under study. Also this study focused only on one social media network group limiting the variety in using social media to be able to compare different types of social media platforms. It was found that most of social media users in Egypt use Facebook, making it the scope of this research rather than comparing different types of social media platforms and different effects that brands may get from different platforms.

\section{Conflicts of Interest}

The author declares no conflicts of interest regarding the publication of this paper.

\section{References}

[1] Mihalcea, A.D. and Savulescu, R.M. (2013) Social Networking Sites: Guidelines for Creating New Business Opportunities through Facebook, Twitter and LinkedIn. Management Dynamics in the Knowledge Economy, 1, 39-54.

[2] Bruhn, M., Schoenmueller, V. and Schäfer, D.B. (2012) Are Social Media Replacing Traditional Media in Terms of Brand Equity Creation? Management Research Review, 35, 770-790. https://doi.org/10.1108/01409171211255948

[3] Mangold, W.G. and Faulds, D.J. (2009) Social Media: The New Hybrid Element of the Promotion Mix. Business Horizons, 52, 357-365.

https://doi.org/10.1016/j.bushor.2009.03.002

[4] Milewicz, C. and Saxby, C. (2013) Leaders' Social Media Usage Intentions for in-Bound Customer Communications. Management Research Review, 36, 849-867. https://doi.org/10.1108/MRR-03-2012-0049

[5] As'ad, H.A.I.R. and Al Hadid, A.Y. (2014) The Impact of Social Media Marketing on Brand Equity: An Empirical Study on Mobile Service Providers in Jordan. Review of Integrative Business and Economics Research, 3, 315.

[6] Heidemann, J., Klier, M. and Probst, F. (2012) Online Social Networks: A Survey of a Global Phenomenon. Computer Networks, 56, 3866-3878.

https://doi.org/10.1016/j.comnet.2012.08.009

[7] Internet World Stats (2017) World Internet Users Statistics Usage and World Population Stats. http://www.internetworldstats.com/stats.htm

[8] Ministry of Communication and Information Technology (MCIT) (2018) Summary Report of Communication and Information Technology Indicators in Egypt 2014; 2015; 2017. http://www.mcit.gov.eg/Indicators/indicators.aspx

[9] AnnualReports (2017) Facebook Annual Report. http://www.annualreports.com/Company/facebook

[10] Kim, A.J. and Ko, E. (2010) Impacts of Luxury Fashion Brand's Social Media Marketing on Customer Relationship and Purchase Intention. Journal of Global Fashion Marketing, 1, 164-171. https://doi.org/10.1080/20932685.2010.10593068

[11] Babac, R. (2011) Impact of Social-Media Use on Brand Equity of Magazine Brands: A Qualitative Study of Vogue Turkey. 
[12] Marzouk, W.G. (2016) Usage and Effectiveness of Social Media Marketing in Egypt: An Organization Perspective. Jordan Journal of Business Administration, 12, 209-238. https://doi.org/10.12816/0030062

[13] Dubai School of Government (2013) Transforming Education in the Arab World: Breaking Barriers in the Age of Social Learning. http://www.ArabSocialMediaReport.com

[14] Taprial, V. and Kanwar, P. (2012) Understanding Social Media. Bookboon, London.

[15] Karamian, H., Nadoushan, M.A. and Nadoushan, A.A. (2015) Do Social Media Marketing Activities Increase Brand Equity. International Journal of Economy, Management and Social Sciences, 4, 362-365.

[16] Aaker, D.A. (1996) Measuring Brand Equity across Products and Markets. California Management Review, 38, 102. https://doi.org/10.2307/41165845

[17] Aaker, D.A. and Joachimsthaler, E. (2000) Brand Leadership: Building Assets in an Information Economy. Simon and Schuster, New York.

[18] Kaplan, A.M. and Haenlein, M. (2010) Users of the World, Unite! The Challenges and Opportunities of Social Media. Business Horizons, 53, 59-68. https://doi.org/10.1016/j.bushor.2009.09.003

[19] Laroche, M., Habibi, M.R. and Richard, M.O. (2013) To Be or Not to Be in Social Media: How Brand Loyalty Is Affected by Social Media? International Journal of Information Management, 33, 76-82.

https://doi.org/10.1016/j.ijinfomgt.2012.07.003

[20] DiMauro, V. and Bulmer, D. (2014) The-Social-Consumer-Study. The Society for New Communications Research.

[21] McKinsey (2007) How Businesses Are Using Web 2.0: A McKinsey Global Survey. The McKinsey Quarterly.

[22] André, A.R.Q. (2015) Consumer Engagement with a Brand on Facebook. Doctoral Dissertation.

[23] Yazdanparast, A., Joseph, M. and Muniz, F. (2016) Consumer Based Brand Equity in the 21st Century: An Examination of the Role of Social Media Marketing. Young Consumers, 17, 243-255. https://doi.org/10.1108/YC-03-2016-00590

[24] Ismail, A.R. (2017) The Influence of Perceived Social Media Marketing Activities on Brand Loyalty: The Mediation Effect of Brand and Value Consciousness. Asia Pacific Journal of Marketing and Logistics, 29, 129-144. https://doi.org/10.1108/APJML-10-2015-0154 